\title{
Reproduction of Phylloderma stenops in captivity (Chiroptera, Phyllostomidae)
}

\author{
Esbérard, CEL.* \\ Laboratório de Diversidade de Morcegos, Instituto de Biologia, Universidade Federal Rural do Rio de Janeiro - UFRRJ, \\ CP 74507, CEP 23851-970, Seropédica, Rio de Janeiro, RJ, Brazil \\ *e-mail: cesberard@ superig.com.br
}

Received November 30, 2010 - Accepted February 4, 2011 - Distributed February 29, 2012

(With 2 figures)

\begin{abstract}
A reproductive colony of Phylloderma stenops was established in captivity. The bats were maintained in 1/2" wired screen cages sized $90 \times 60 \times 80 \mathrm{~cm}$ in a room with cycles of 13 hours of light and 11 hours of dark and with temperature and humidity ranging from 27 to $31{ }^{\circ} \mathrm{C}$ and 75 to $90 \%$ respectively. Bats were fed with a semi-liquid diet composed of chopped fruits, raw eggs, bovine meat, dog food, honey, dehydrated shrimp, salt and a vitamin and mineral complex offered daily. In the first two years of confinement the diet was complemented with laboratory-raised cockroaches, mealworms, young mice and seasonal fruits. Nine births occurred from three wild caught females 770-1050 days after capture and two captive-born females. Births occurred in September, February and November-December. The neonate measured $15.0 \mathrm{~g}$ of weight and present $34.1 \mathrm{~mm}$ of forearm length. Two captive-born females gave birth for the first time at 402-445 days of age. Phylloderma stenops species presents postpartum oestrus, gestation of 5.5 months, lactation of 3.3 months and sexual maturity at 8.0-8.5 months. Fetuses are palpable around two months before birth and females may present synchronisation of births.
\end{abstract}

Keywords: reproduction, sexual maturity, gestation, neonate.

\section{Reprodução de Phylloderma stenops Peters em cativeiro (Mammalia, Chiroptera, Phyllostomidae)}

\begin{abstract}
Resumo
Uma colônia reprodutiva de Phylloderma stenops foi implantada em cativeiro. Os morcegos foram mantidos em gaiolas de tela de arame de 1/2", com tamanho de $90 \times 60 \times 80 \mathrm{~cm}$, em sala com ciclo de 13 horas de luz e 11 horas de escuro, com temperatura e umidade variando de 27 a $31{ }^{\circ} \mathrm{C}$ e 75 a $90 \%$, respectivamente. Nove nascimentos ocorreram durante o estudo envolvendo três fêmeas selvagens e duas nascidas em confinamento. Os morcegos foram alimentados com dieta semilíquida composta por frutas picadas, ovos cozidos, carne bovina, ração de cachorro, mel, camarões desidratados, sal e complexos vitamínicos, oferecida diariamente. Nos dois primeiros anos de confinamento, a dieta foi complementada com baratas criadas em cativeiro, larvas de tenebrio, camundongos jovens e frutas sazonais. Nove partos ocorreram entre três fêmeas selvagens 770-1050 dias após a captura e duas fêmeas concebidas em cativeiro. Os nascimentos ocorreram em setembro, fevereiro e dezembro. O neonato pesou 15,0 g e apresentou 34,1 mm de comprimento do antebraço. Duas fêmeas concebidas em cativeiro pariram com idade de 402-445 dias. Phylloderma stenops apresenta estro pós-parto, gestação de 5,5 meses, lactação de 3,3 meses e maturidade sexual aos 8,0-8,5 meses. Fetos são detectáveis através de apalpação cerca de dois meses antes do nascimento e as fêmeas podem apresentar sincronização dos nascimentos.
\end{abstract}

Palavras-chave: reprodução, maturidade sexual, gestação, neonato. 


\section{Introduction}

Few species of Phyllostomid bats have been kept captive by zoological gardens and research centers so far in comparison with species of Pteropodidae (e.g. Barnard, 1995). Up to date only a few species of bats have been bred in captivity (Barnard, 1995; McCracken and Wilkinson, 2000; Esbérard et al., 2006). Captive conditions facilitate observations of the reproductive biology of a species which are difficult to observe and document in the wild. Although comparisons between captive and free animals can be challenging, controlled conditions of some important environmental variables such as temperature, humidity, and day-night cycles in zoos and research centres make the study of aspects such as sexual maturity and length of gestation more accessible (e.g. Delpietro and Russo, 2006).

Phylloderma stenops Peters, 1865 occurs in the Amazonian Forest, in the Cerrado and in the Atlantic Forest south of São Paulo state (Simmons, 2005). Despite its wide geographic distribution, this species is rarely netted and most of the published capturing records resulted from samplings close to caves where the species has been found in small heterosexual groups (e.g. Trajano, 1995; Bredt et al., 1999; Esbérard et al., 2005). This species is considered an omnivore based on the scarcely available reports in the literature (Jeanne, 1970; Gardner, 1977).

This species has not been previously maintained in captivity. The objective of this work is to document the reproductive biology of $P$. stenops in captive conditions at Rio de Janeiro Zoological Garden (RIOZOO Foundation).

\section{Material and Methods}

The bats were captured in the Conservation Unit Nascentes do Rio Vermelho, Mambaí, Goiás state, in 2002 $(\mathrm{N}=3)$ and at Morro de São João, Casimiro de Abreu, Rio de Janeiro state in $2001(\mathrm{~N}=2)$. Animals were kept isolated in quarantine for 12 or more months and later combined in one group in the summer of 2003. The group was formed of one male and one female captured in Goiás state and two females captured in Rio de Janeiro state.

The group was maintained in $1 / 2$ " wired screen cages of $90 \times 60 \times 80 \mathrm{~cm}$ corresponding to length, width and height (Figure 1) inside a room where other species of bats were also maintained under automatically controlled cycles of 13 hours of artificial light and 11 hours of dark by complementing the natural light if necessary. A total of 16 species of bats of Phyllostomidae, Noctilionidae, Molossidae and Vespertilionidae was maintained in this facility without sound or vision isolation, and reproductive success was obtained in eight species (six species of Phyllostomidae and two Noctilionidae). Temperature and humidity ranged between 27 to $31^{\circ} \mathrm{C}$ and 75 to $90 \%$ respectively and was controlled by exhaustion, humidity controllers and heaters. These conditions is suitable to most species of bats maintained in this facility (Esbérard and Gomes, 2001), although some fur losses can be observed and eventually needed to be controlled by reducing humidity to $75 \%$.

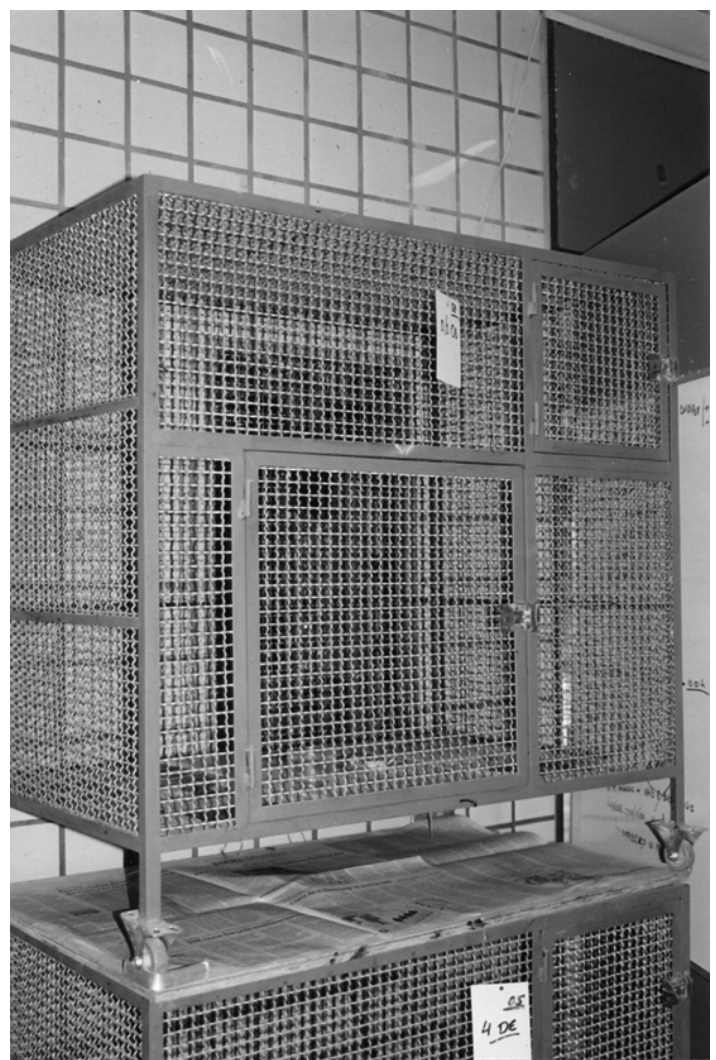

Figure 1. Detail of the wired cages used to maintain Phylloderma stenops and other phyllostomid species in captivity at RIOZOO Foundation.

Bats were fed with a semi-liquid diet composed by chopped fruits (banana, apple, papaya, orange, guava and pineapple), raw eggs, bovine meat, dog food, honey, dehydrated shrimp, salt and a vitamin and mineral complex offered daily. Food was always offered by 3:00 PM. In the first two years of confinement the diet was complemented with laboratory-raised cockroaches, mealworms, young mice and seasonal fruits (mango, avocado and kaki mainly). From the second year onward the food complementation was restricted to breeding females. All live food was readily ingested and few bats showed a notable preference to bananas and avocado.

The animals were identified by both microchips Animal Tag and plastic necklaces with colour cylinders and were observed twice daily for 10 minutes each time during the husbandry activities, usually at 10:00 AM and 3:00 PM. To avoid parent predation or abandonment, each neonate were measured (forearm length and weight) a single time during the lactation period. A linear regression between age and weight and between ages and forearm length was achieved using the measurements of the nine offspring.

\section{Results}

Nine births, comprising four males and five females were obtained, from the three founder females (770 and 
1,050 days after capture) and two captive-born females (first generation bats). The first birth was observed in 09/13-14/2004, with the three females giving birth within 18-30 hours interval and producing a male and two females. These neonates were only measured during weaning time at 97 days of age (12/21/2004). At this age juveniles presented forearm lengths similar in size of that of the adults, however, with still smaller body weights (about $84.7 \%$ of the parent's weight). At December/2004 it was observed that two of the three lactating females already presented palpable fetuses (64 days prior the second birth), confirming the existence of a postpartum oestrus in this species. The second birth of each female happened between 161-166 days after the first birth (births in 02/21/2005 and $02 / 26 / 2005$ ). A third round of births, involving the same females, occurred on 12/02/2005 (with intervals of 284 and 289 days from the second births). Two more births were observed in November and December 2005 (Figure 2).

One neonate abandoned (less than 24 hours from birth) but still alive was found in the morning, probably attacked by his mother as judged by several wounds and died a few hours later. This neonate measured $15.0 \mathrm{~g}$ of weight and present $34.1 \mathrm{~mm}$ of forearm length (Table 1). The development of the youngs resulted in the increase of weight $=0.439 *$ days $+25.84\left(\mathrm{R}^{2}=0,78, \mathrm{~F}=24.29\right.$, $\mathrm{p}=0.002)$ and forearm length $=0.458 *$ days +39.99 $\left(\mathrm{R}^{2}=0.90, \mathrm{~F}=57,599, \mathrm{p}>0.001\right)$. Two captive born females conceived in September of 2004 gave birth for the first time in November and December of 2005 at 402-445 days of age. By subtracting the smallest interval among the observed births (161 days), it is inferred that sexual maturity is reached around the age of 241-285 days.

\section{Discussion}

The birth synchronisation observed for P. stenops in captivity, with five births occurring in 18-30 hours intervals, has been previously described for the closely related $P$. hastatus (Porter and Wilkinson, 2001). The average weight of $P$. stenops neonate (21.4\% of the mother's weight) is comparable with the weights reported for captive Phyllostomus hastatus neonates (20.5\%). Neonates of Phyllostomid bats present average weights ranging from 18.6 to $32.5 \%$ of the maternal weight in captivity (Kurta and Kunz, 1987; Badwaik and Raisweiler, 2000; Kunz and Hood, 2000; Esbérard et al., 2006).

The gestational period probably will not exceed $164-$ 167 days in $P$. stenops as considering the birth intervals observed in our study. This gestation length is close to that expected for the biomass of this species (Esbérard et al., 2006). The literature reports that at least 12 species of phyllostomid showed the occurrence of a postpartum oestrus. Rasweiler and Badwaik (1996) analysed the occurrence of the postpartum oestrus in captive Carollia perspicillata (Linnaeus, 1758) and discovered the onset of the new oestrus 3-6 days after the first birth. In species with postpartum oestrus the interval between births is frequently equal or slightly longer than the gestation period. The interval between two consecutive births observed in this species is longer

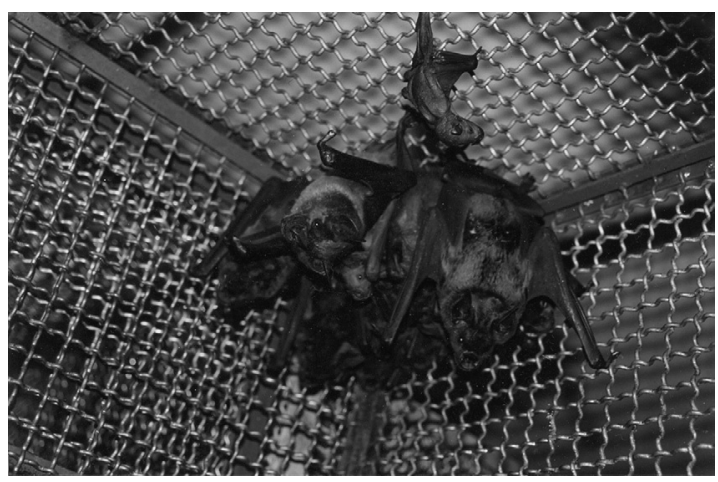

Figure 2. Group of Phylloderma stenops maintained in captivity, composed by seven adults (two males and five females) and two neonates in RIOZOO Foundation at December, 2005.

Table 1. Weights and forearm lengths of wild and captive-born Phylloderma stenops. Age of the wild caught individuals is indicated by the interval between the capture and the first birth.

\begin{tabular}{|c|c|c|c|c|c|}
\hline Bat & Generation & Age (days) & Weight (g) & Forearm length $(\mathrm{mm})$ & Sex \\
\hline 1 & Wild & $>770$ & 80.6 & 84.36 & $\hat{0}$ \\
\hline 2 & Wild & $>770$ & 74.0 & 81.67 & q \\
\hline 3 & Wild & $>1050$ & 77.9 & 77.45 & q \\
\hline 4 & Wild & $>1050$ & 71.6 & 83.34 & 우 \\
\hline 5 & F1 & 97 & 71.1 & 82.37 & $\hat{\sigma}$ \\
\hline 6 & $\mathrm{~F} 1$ & 97 & 58.0 & 82.85 & q \\
\hline 7 & F1 & 97 & 64.0 & 82.35 & q \\
\hline 8 & $\mathrm{~F} 1$ & 25 & 45.1 & 49.25 & $\delta$ \\
\hline 9 & $\mathrm{~F} 1$ & 30 & 54.0 & 60.25 & 우 \\
\hline 10 & $\mathrm{~F} 1$ & 1 & 15.0 & 34.10 & q \\
\hline 11 & $\mathrm{~F} 1$ & 7 & 22.0 & 36.10 & $\widehat{0}$ \\
\hline 12 & $\mathrm{~F} 2$ & 67 & 65.0 & 72.20 & 0 \\
\hline 13 & $\mathrm{~F} 2$ & 27 & 35.0 & 65.50 & 움 \\
\hline
\end{tabular}


than that observed in frugivorous bat Artibeus jamaicensis Leach, 1821 (122 days, Taft and Handley, 1991; Ortega and Castro-Arellano, 2001) and shorter than that observed in the hematophagus bats Desmodus rotundus (E. Geoffroy, 1810), Diphylla ecaudata Spix, 1823 (365 days for both, Delpietro and Russo, 2002) and in the carnivore bat Chrotopterus auritus (Peters, 1856) (369-770 days, Esbérard et al., 2006).

Phylloderma stenops presented sexual maturity at 241 days of age in captive conditions which falls under 12 months of age as it has also been described for D. rotundus (285 days, Delpietro and Russo, 2002), but the birth of the first litter was observed more than 12 months from the birthday of the mother.

With these observations it is secure to affirm that P. stenopus shows a poliestric strategy, with seasonal reproductive season and presents birth synchrony and postpartum oestrus.

Acknowledgements - We thank the Centro Nacional de Estudo de Cavernas/IBAMA, Fazendas Reunidas, Morro de São João for financial support in the field activities and Anderson Mendes Augusto and Adarene Guimarães Motta of Fundação RIOZOO, Quinta da Boa Vista, Rio de Janeiro, RJ, Brasil. This work was performed under approval of IBAMA (Processes 1785/89-IBAMA and 4156/95-46 AC-SUPES/DF/IBAMA). The author received $\mathrm{CNPq}$ funding through a research grant (number 301061/2007-6) and a scholarship from FAPERJ (E26/102.201/2009) and CNPq (152910/2004-0).

\section{References}

BADWAIK, NK. and RAISWEILER JJ. IV., 2000. Pregnancy. In CRICHTON, EG. and KRUTZSCH, PH. (Eds.). Reproductive biology of bats. London: Academic Press. p. 221-293.

BARNARD, S., 1995. Bats in captivity. Springville: Wild Ones Animal Books. $194 \mathrm{p}$

BREDT, A., UIEDA, W. and MAGALHÃES, ED., 1999. Morcegos cavernícolas da região do Distrito Federal, Centrooeste do Brasil (Mammalia, Chiroptera). Revista Brasileira de Zoologia, vol. 16, no. 3, p. 731-770. http://dx.doi.org/10.1590/ S0101-81751999000300012

DELPIETRO, VHA. and RUSSO, RG., 2002. Observations of the common vampire bat (Desmodus rotundus) and the hairylegged vampire bat (Diphylla ecaudata) in captivity. Mammalian Biology, vol. 67, no. 1, p. 65-78.

ESBÉRARD, CEL. and GOMES, LH., 2001. Order Chiroptera. In FOWLER, ME. and CUBAS, ZS. (Eds). Biology, medicine, and surgery of South American Wild Animals. Ames: Iowa University Press. p. 219-224.
ESBÉRARD, CEL., MOTA, JA. and PERIGO, C., 2005. Morcegos cavernícolas da APA Nascentes do Rio Vermelho, Goiás. Revista Brasileira de Zoociencias, vol. 7, no. 2, p. 311-325.

ESBÉRARD, CEL., MOTTA, AG., ALMEIDA, JC., FERREIRA, LCS. and COSTA, LM., 2006. Reproduction of Chrotopterus auritus (Peters) in captivity (Chiroptera, Phyllostomidae). Revista Brasileira de Biologia = Brazilian Journal of Biology, vol. 66, no. 3, p. 955-956. PMid:17119844.

GARDNER, AL., 1977. Feeding habits. In BAKER, RJ., JONES JUNIOR, JK. and CARTER, DC. (Eds). Biology of bats of the New World family Phyllostomidae. The Museum Texas Tech University Special Publications. p. 293-350. part 3, vol.13.

JEANNE, RL., 1970. Note on a bat (Phylloderma stenops) preying upon the brood of a social wasp. Journal of Mammalogy, vol. 51, no. 3, p. 624-625. http://dx.doi.org/10.2307/1378408

KUNZ, TH. and HOOD WR., 2000. Parental care and postnatal growth in the Chiroptera. In CRICHTON, EG. and KRUTZSCH, PH. (Eds). Reproductive biology of bats. London: Academic press, 510 p. pp. $363-414$

KURTA, A. and KUNZ, TH., 1987. Size of bats at birth and maternal investment during pregnancy. Symposia of the Zoological Society of London, vol. 57, no. 1, p. 79-106.

McCRAKEN, GF. and WILKINSON, GS., 2000. Bat mating systems. In CRICHTON, EG. and KRUTZSCH, PH. (Eds.). Reproductive biology of bats. London: Academic Press. p. 321-362.

PORTER, TA. and WILKINSON, GS., 2001. Birth synchrony in greater spear-nosed bats (Phyllostomus hastatus). Journal of Zoology, vol. 253, no. 2, p. 383-390.

ORTEGA, J. and Castro-Arellano, I., 2001. Artibeus jamaicensis. Mammalian Species, vol. 662, p. 1-9. http://dx.doi.org/10.1644/15451410(2001)662\%3C0001:AJ\%3E2.0.CO;2

RASWEILER, JJ. IV and BADWAIK, NK., 1996. Delayed development in the short-tailed fruit bat, Carollia perspicillata. Journal of Reproduction and Fertility, vol. 109, no. 1, p. 7-20.

SIMMONS, NB., 2005. Order Chiroptera. In WILSON, DE. and REEDER, DM. (Eds). Mammal species of the world: a taxonomic and geographic reference. Baltimore: Johns Hopkins University Press. pp 312-529.

TAFT, LK. and HANDLEY JUNIOR, CO., 1991. Reproduction in a captive colony. In HANDLEY, CO., WILSON, DO. and GARDNER, AL. (Eds). Demography and natural history of the common fruit bat Artibeus jamaicensis on Barro Colorado Island, Panama. Smithsonian Contributions to Zoology, vol. 511, p. 1-173.

TRAJANO, E., 1985. Ecologia de populações de morcegos cavernícolas em uma região cárstica do sudeste do Brasil. Revista Brasileira de Zoologia, vol. 2, no. 5, p. 255-320. http://dx.doi. org/10.1590/S0101-81751984000100001 